Recommended by Doctor of Pharmacy, Professor S. I. Merzlikin

UDC 615.282:54.057:547.77

P. V. Tkachenko, O. V. Tkachenko, K. Yu. Netosova, O. V. Borisov*, I. O. Zhuravel**

National University of Pharmacy

* Enamine Ltd.

** Kharkiv Medical Academy of Postgraduate Education

\title{
The synthesis of the substituted 4-alkyl/arylsulfonyl-5-amino-3- alkylthiopyrazoles as promising pharmaceutical agents with the antifungal action
}

One of the promising directions for development of antifungal agents is the synthesis of new chemical compounds that can be used as active pharmaceutical ingredients to produce highly effective drugs for the treatment of fungal infestations.

Aim. To create the combinatorial library of 4-alkyl/arylsulfonyl-5-amino-3-alkylthiopyrazoles derivatives for the total antimicrobial screening to search for new substances with the antifungal activity, and study their spectral properties.

Materials and methods. The methods of organic synthesis, instrumental methods of organic compound analysis were used.

Results and discussion. The design of the library of small molecules based on the core structure of 5-aminopirazole has been developed. The useful and effective synthetic scheme for preparing $\mathrm{N}^{1}$-subsituted 4-alkyl/arylsulfonyl-5-amino3-alkylthiopyrazoles and their acylation products has been proposed and approved. This approach consists of cyclization of substituted alkyl/arylsulfoacetonitriles under the action of hydrazine hydrate with further alkylation and acylation of 5-aminopyrazoles obtained. The total yield of the target products is 50-85\%. The structure of all compounds synthesized has been confirmed using elemental analysis, ${ }^{1} \mathrm{H}$ NMR- and chromato-mass spectrometric methods.

Conclusions. The design and the synthetic scheme for obtaining 4-alkyl/arylsulfonyl-5-amino-3-alkiltiopirazoles and products of their chemical modification have been proposed. The compounds synthesized are of certain interest as potential pharmaceutical agents and can be used to develop new antifungal agents.

Key words: pyrazole; combinatorial library; synthesis; pharmaceutical agents

П. В. Ткаченко, О.В.Ткаченко, К. Ю. Нетьосова, О. В. Борисов, І.О.Журавель

Синтез заміщених 4-алкіл/арилсульфоніл-5-аміно-3-алкілтіопіразолів як потенційних фармацевтичних агентів протигрибкової дії

Одним з перспективних напрямків терапії грибкових інфекцій є синтез нових хімічних сполук, які можуть бути використані в якості активних фармацевтичних інгредієнтів у виробництві високоефективних ліків для лікування грибкових інвазій.

Мета роботи. Запропонувати дизайн комбінаторної бібліотеки похідних 4-алкіл/арилсульфоніл-5-аміно-3алкілтіопіразолів для тотального антимікробного скринінгу з метою пошуку нових речовин з протигрибковою активністю, розробити методи синтезу нових сполук, вивчити їх спектральні характеристики.

Матеріали та методи. Використовувалися методи органічного синтезу, інструментальні методи аналізу органічних сполук.

Результати та їх обговорення. Розроблено дизайн бібліотеки малих молекул на основі базової структури 5-амінопіразолу. Запропоновано і апробовано зручну та ефективну синтетичну схему одержання $\mathrm{N}^{1}$-заміщених 4-алкіл/арилсульфоніл-5-аміно-3-алкілтіопіразолів та продуктів їх ацилювання. Даний підхід полягає в циклізації заміщених алкіл/арилсульфонілацетонітрилів під дією гідразин-гідрату з подальшим розширенням хімічного різномаїття структур за рахунок реакцій алкілування та ацилювання. Загальний вихід цільових продуктів складає 50-88 \%. Структура всіх синтезованих сполук підтверджена даними елементного аналізу, ${ }^{1} \mathrm{H}$ ЯМР- та LC/MS-методів.

Висновки. Запропоновано дизайн та синтетичну схему одержання нових похідних 4-алкіл/арилсульсроніл5-аміно-3-алкілтіопіразолів та продуктів їх хімічної модифікації. Синтезовані сполуки становлять певний інтерес як потенційні фрармацевтичні агенти і можуть бути використані в розробці нових протигрибкових засобів.

Ключові слова: піразол; комбінаторна бібліотека; синтез; фрармацевтичний агент

П. В. Ткаченко, Е. В. Ткаченко, К. Ю. Нетёсова, А. В. Борисов, И. А. Журавель

Синтез замещенных 4-алкил/арилсульфонил-5-амино-3-алкилтиопиразолов как потенциальных фрармацевтических агентов противогрибкового действия

Одним из перспективных направлений терапии грибковых инфекций является синтез новых химических соединений, которые могут быть использованы в качестве активных фрармацевтических ингредиентов в производстве высокоэффективных лекарств для лечения грибковых инвазий.

Цель работы. Предложить дизайн комбинаторной библиотеки производных 4-алкил/арилсульфонил-5амино-3-алкилтиопиразолов для тотального антимикробного скрининга с целью поиска новых веществ с противогрибковой активностью, разработать методы синтеза новых соединений, изучить их спектральные характеристики. 
Материалы и методы. Использовались методы органического синтеза, инструментальные методы анализа органических соединений.

Результаты и их обсуждение. Разработан дизайн библиотеки малых молекул на основе базовой структуры 5-аминопиразола. Предложена и апробирована удобная и эффективная синтетическая схема получения $\mathrm{N}^{1}$-замещенных 4-алкил/арилсульфонил-5-амино-3-алкилтиопиразолов и продуктов их ацилирования. Данный подход состоит в циклизации замещенных алкил/арилсульфонилацетонитрилов под действием гидразин-гидрата с последующим расширением химического разнообразия веществ за счет реакций алкилирования и ацилирования. Общий выход целевых продуктов составил 50-88 \%. Структура всех синтезированных соединений подтверждена данными элементного анализа, ${ }^{1} \mathrm{H}$ ЯMP- и LC/MS-методов.

Выводы. Предложен дизайн и синтетическая схема получения новых производных 4-алкил/арилсульфонил5-амино-3-алкилтиопиразолов и продуктов их химической модификации. Синтезированные соединения представляют определенный интерес в качестве потенциальных фармацевтических агентов и могут быть использованы для разработки новых противогрибковых средств.

Ключевые слова: пиразол; комбинаторная библиотека; синтез; фрармацевтический агент

The global spread of fungal infections trend tends to increase [1-6]. This is directly due to the high mobility of the population and because of the increasing proportion of the elderly people in its structure. It can be considered as a constant source of infections. Today more than 400 species of fungi that can cause disease in humans are known. The spectrum of potential fungal pathogens continues to expand, but the dominant clinical value remains Candida and Aspergillus spp [3]. The mortality rate for some forms of Candida infection is $38-75 \%$, and for invasive aspergillosis this index exceeds $95 \%$ [3]. It should be noted that the effectiveness of the existing pharmaceutical market of antifungal drugs decreases in proportion to the increase in their use due to the spread of resistant clinical strains and is characteristic of all antimicrobial agents.

One of the promising directions for development of antifungal agents is the synthesis of new chemical compounds that can be used as active pharmaceutical ingredients to produce highly effective drugs for the treatment of fungal infestations. Modern developments in the field of chemistry of antifungal agents are new triazoles [7-9], echinocandines [9, 10], imidazoles [10] and pyrazoles [11-16].

\section{Materials and methods}

All solvents and reagents were obtained from the commercial sources. Elemental analysis was performed on a Euro EA-3000 apparatus. Melting points were obtained on a Buchi B-520 device. The NMR-spectra were recorded with a Bruker 170 Avance 500 spectrometer at $500 \mathrm{MHz}$ (DMSO-d6); TMS was used as an internal standard; chemical shifts were reported in ppm. LC/MS spectra were recorded with a PE SCIEX API 150EX liquid chromatograph equipped with a UV detector (215 and $254 \mathrm{~nm})$ and using the $C 18$ column $(100 \times 4 \mathrm{~mm})$. Elution started with water and ended with acetonitrile/ water $(95: 5, \mathrm{v} / \mathrm{v})$; the linear gradient was used at the flow rate of $0.15 \mathrm{~mL} / \mathrm{min}$ and the analysis cycle time of $25 \mathrm{~min}$. According to LC/MS data all compounds synthesized have purity $>95 \%$. The TLC was performed on aluminum plates covered with silica gel (Merck, Kiesgel 60 F-254).

The substituted 4-alkyl/arylsulfonyl-5-amino-3alkylthiopyrazoles (3) were obtained according to the methods previously reported [17].
The general procedure for $N^{I}$-alkylation 4-alkyl/ arylsulfonyl-5-amino-3-alkylthiopyrazoles (5). To the mixture of 4-alkyl/arylsulfonyl-5-amino-3-alkylthiopyrazoles $(1 \mathrm{mmol})$ and $\mathrm{K}_{2} \mathrm{CO}_{3}(3 \mathrm{mmol})$ in DMF $(10 \mathrm{~mL})$ add the appropriate halide $(1.2 \mathrm{mmol})$. Stir the reaction mixture at $80^{\circ} \mathrm{C}$ for $1 \mathrm{~h}$ and then cooled to the room temperature. Add water $(60 \mathrm{~mL})$, filter the precipitate formed, then crystallize from the mixture of ethanol/DMF $(1: 1)$.

The general procedure for preparation of $5-(\mathrm{N}-$ acylamino)-derivatives $N^{l}$-substituted 4-alkyl/arylsulfonyl-5-amino-3-alkylthiopyrazoles (7). Reflux the mixture of $N^{I}$-alkylation 4-alkyl/arylsulfonyl-5-amino-3-alkylthiopyrazole $(1.5 \mathrm{mmol})$ and the corresponding chloroanhydride of carboxylic acid $(1.7 \mathrm{mmol})$ in dioxane $(10 \mathrm{~mL})$ for $2 \mathrm{~h}$, then cool the mixture to the room temperature and dilute with water $(10 \mathrm{~mL})$. Filter the precipitate, wash with water $(2 \times 5 \mathrm{~mL})$ and methyl alcohol $(7 \mathrm{~mL})$.

The general procedure for preparation of 5- $(\mathrm{N}, \mathrm{N}-$ diacylamino)-derivatives of $N^{I}$-substituted 4-alkyl/ arylsulfonyl-5-amino-3-alkylthiopyrazoles (9). Reflux the mixture of $N^{I}$-alkylation 4-alkyl/arylsulfonyl-5-amino3 -alkylthiopyrazole $(1.5 \mathrm{Mol})$ and the corresponding anhydride $(1.7 \mathrm{Mol})$ in dioxane $(10 \mathrm{~mL})$ for $2 \mathrm{~h}$, then cool the mixture to the room temperature and dilute with water $(10 \mathrm{~mL})$. Filter the precipitate and wash with water $(2 \times 5 \mathrm{~mL})$.

\section{Results and discussion}

Recently, we described the synthesis and the antimicrobial activity of some 4-arylsulfonylderivatives of 5 -aminopyrazoles and proposed some directions of modification of the pyrazole system for enhancing their action [17]. In this paper the synthetic scheme was proposed. It allows generating structures that combine several fragments characteristic of compounds with the antifungal action. Based on the analysis using the PASS (Prediction of Activity Spectra for Substances) computer program [18] 5-aminopirazole with the substituted sulfonyl-group in position 4 and with branched radicals in position 1 was chosen as a basic structure.

Our approach is in application of the useful and effective synthetic scheme for preparation of $N^{I}$-subsituted 4-alkyl/arylsulfonyl-5-amino-3-alkylthiopyrazoles starting from substituted sulfoacetonitriles shown in Tab. 1. The first stage of the reaction is the cyclization of the 
Alkylsulfoacetonitriles $\mathbf{1}\{1-2\}$ and arylsulfoacetonitriles $\mathbf{1}\{3-6\}$

\begin{tabular}{|c|c|c|}
\hline Entry & Compound & R $^{1}$ \\
\hline 1 & $\mathbf{1}\{1\}$ & Methyl \\
\hline 2 & $\mathbf{1}\{2\}$ & Ethyl \\
\hline 3 & $\mathbf{1}\{3\}$ & Phenyl \\
\hline 4 & $\mathbf{1}\{4\}$ & 4-methylphenyl \\
\hline 5 & $\mathbf{1}\{5\}$ & 4-chlorophenyl \\
\hline 6 & $\mathbf{1}\{6\}$ & 4-methoxyphenyl \\
\hline
\end{tabular}

Table 2

Alkyl halides 2\{1-18\}

\begin{tabular}{|c|c|c|}
\hline Entry & Compound & $\mathrm{R}^{2}$ and $\mathrm{R}^{3}$ \\
\hline 1 & $\mathbf{2}\{1\}$ & Methyl \\
\hline 2 & $\mathbf{2}\{2\}$ & Ethyl \\
\hline 3 & $\mathbf{2}\{3\}$ & n-propyl \\
\hline 4 & $\mathbf{2}\{4\}$ & i-propyl \\
\hline 5 & $\mathbf{2}\{5\}$ & Benzyl \\
\hline 6 & $\mathbf{2}\{6\}$ & 2-methylbenzyl \\
\hline 7 & $\mathbf{2}\{7\}$ & 3-methylbenzyl \\
\hline 8 & $\mathbf{2}\{8\}$ & 4-methylbenzyl \\
\hline 9 & $\mathbf{2}\{9\}$ & 2,4-dimethylbenzyl \\
\hline 10 & $\mathbf{2}\{10\}$ & 2,5-dimethylbenzyl \\
\hline 11 & $\mathbf{2}\{11\}$ & 3-methoxybenzyl \\
\hline 12 & $\mathbf{2}\{12\}$ & 2-fluorobenzyl \\
\hline 13 & $\mathbf{2}\{13\}$ & 4-fluorobenzyl \\
\hline 14 & $\mathbf{2}\{14\}$ & 2-chlorobenzyl \\
\hline 15 & $\mathbf{2}\{15\}$ & 3-chlorobenzyl \\
\hline 16 & $\mathbf{2}\{16\}$ & 4-chlorobenzyl \\
\hline 17 & $\mathbf{2}\{17\}$ & 4-bromobenzyl \\
\hline 18 & $\mathbf{2}\{18\}$ & 4-ethenylbenzyl \\
\hline
\end{tabular}

corresponding alkyl- 1 $\{1-2\}$ or arylsulfoacetonitriles 1 $\{3-6\}$ with $\mathrm{CS}_{2}$ and alkylhalogenides $2\{1-3\}$ (Tab. 2) in dioxane for introduction of the thioalkyl moiety with the following cyclization under the action of hydrazine hydrate (Scheme). The reaction with hydrazine hydrate was
Chloroacetamides $4\{1-11\}$

\begin{tabular}{|c|c|c|}
\hline Entry & Compound & $\mathrm{R}^{3}$ \\
\hline 1 & $\mathbf{4}\{1\}$ & phenyl \\
\hline 2 & $\mathbf{4}\{2\}$ & 2-ethylphenyl \\
\hline 3 & $\mathbf{4}\{3\}$ & 2,5-dimethylphenyl \\
\hline 4 & $\mathbf{4}\{4\}$ & 3,4-dimethylphenyl \\
\hline 5 & $\mathbf{4}\{5\}$ & 3,5-dimethylphenyl \\
\hline 6 & $\mathbf{4}\{6\}$ & 4-methoxyphenyl \\
\hline 7 & $\mathbf{4}\{7\}$ & 2,4-dimethoxyphenyl \\
\hline 8 & $\mathbf{4}\{8\}$ & 4-chlorophenyl \\
\hline 9 & $\mathbf{4}\{9\}$ & 4-methoxyphenyl \\
\hline 10 & $\mathbf{4}\{10\}$ & 2,4-difluorophenyl \\
\hline 11 & $\mathbf{4}\{11\}$ & 2-fluoro-4-bromophenyl \\
\hline
\end{tabular}

carried out in propanole-2 in the presence of triethylamine traces while boiling for $3 \mathrm{~h}$ and led to target 4-alkyl/arylsulfonyl-5-amino-3-alkylthiopyrazoles $\mathbf{3}\{1-12\}$ in a good yield of 67-89 \% via S,S-diacetales as intermediates. Formation of the pyrazole cycle for compounds 3 was confirmed by the presence of singlet signals of $\mathrm{NH}$ protons at $\delta 11.97 \ldots 12.00 \mathrm{ppm}$ and signals of the amino group at $\delta 5.80 \ldots 6.17 \mathrm{ppm}$.

For the synthesis of $N^{I}$-substituted products $5\{1-146\}$ the alkylation reaction was used. The interaction was carried out by conventional treatment with alkyl halides 2 $\{1-18\}$ and chloroacetamides $4\{1-11\}$ (Tab. 3) in dimethylformamide (DMF) in the presence of $\mathrm{K}_{2} \mathrm{CO}_{3}$ at $80{ }^{\circ} \mathrm{C}$. The yields of the target products were $61-91 \%$ depending on the nature of the reagent. The absence of signals of $\mathrm{NH}$ protons of ${ }^{1} \mathrm{H}$ NMR-spectra of products 5 indicates the $N^{l}$-alkylation reaction. And the presence of cross-coupling between the $\mathrm{CH}_{2}$ protons of the acetamide fragment (approximately at $4.80 \mathrm{ppm}$ ) and the amino group (approximately at $6.50 \mathrm{ppm}$ ) in the NOESY spectra of target products unambiguously confirms the direction of the reaction.

Some of 5-aminopyrazoles 5 obtained were converted in high yields (70-90\%) to the corresponding $N$ acylamino derivatives $7\{1-54\}$ using chloroanhydrides of carboxylic acids $6\{1-3\}$ (Tab. 4). The use of the ex-
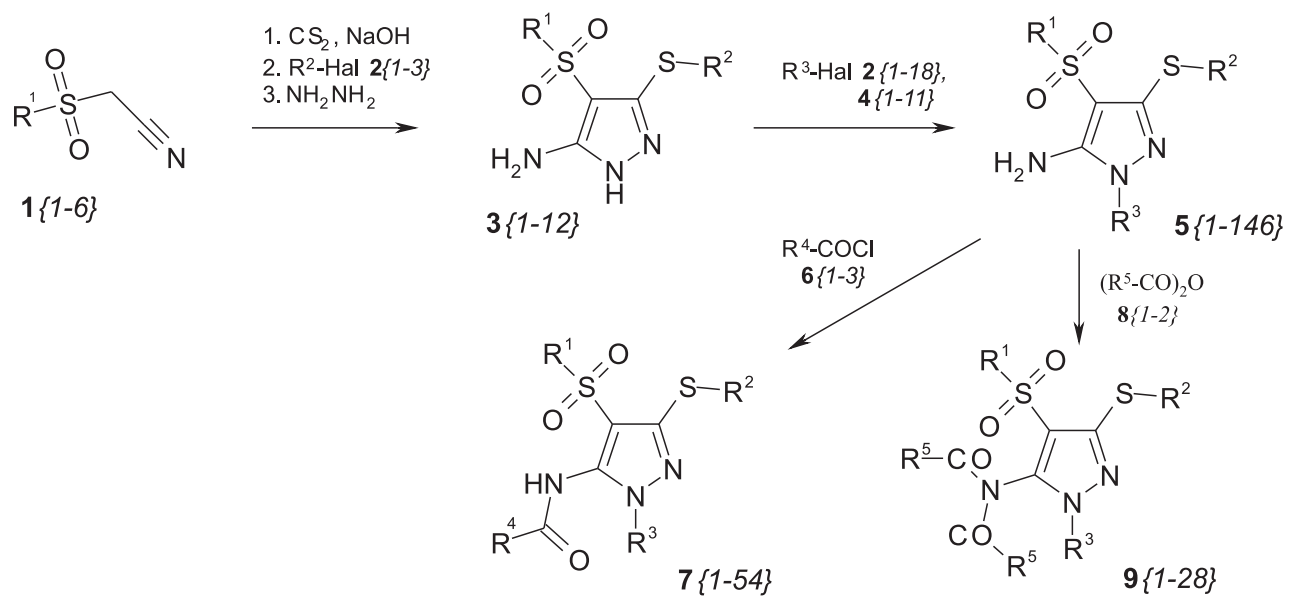

Scheme. Preparation of substituted 4-alkyl/arylsulfonyl-5-amino-3-alkylthiopyrazoles 
Table 4 ties of these compounds are important directions of phar-

Acid chloroanhydrides 6 $\{1-3\}$ and Acid anhydrides $8\{1-2\}$

\begin{tabular}{|c|c|c|}
\hline Entry & Compound & $\mathrm{R}^{4}$ \\
\hline 1 & $\mathbf{6}\{1\}$ & Methyl \\
\hline 2 & $\mathbf{6}\{2\}$ & Ethyl \\
\hline 3 & $\mathbf{6}\{3\}$ & Propyl \\
\hline
\end{tabular}

cess anhydride of carboxylic acids $8\{1-2\}$ in this interaction led to $N, N$-diacylamino derivatives $9\{1-28\}$. In the case of monoacylamino derivatives 7 in the ${ }^{1} \mathrm{H}$ NMRspectra the signal of NH-proton was observed near $10.20 \ldots 10.30 \mathrm{ppm}$. In the case of diacylamino derivatives 9 the signal of NH-proton was absent, and signals of protons of acyl fragments were observed at $0.80 \ldots 0.85 \mathrm{ppm}$ and $2.35 \ldots 2.55 \mathrm{ppm}$ with a double integral intensity.

The structure of all compounds obtained was confirmed using ${ }^{1} \mathrm{H}$ NMR- and chromato-mass spectrometric methods.

For illustration, 8 arbitrary compounds synthesized according to Scheme are shown in Fig.

One can assume that the compounds synthesized have a broad potential of the pharmacological activity, especially as antifungal agents; and development of methods of the synthesis and the study of pharmacological proper- maceutical and medical chemistry.

5-Amino-4-phenylsulfonyl-3-methylthiopyrazole $3\{3\}$. Yield $-87 \%$. M. p. $-188^{\circ} \mathrm{C}$; ${ }^{1} \mathrm{H}$ NMR $\delta: 2.43$ $\left(\mathrm{s}, 1 \mathrm{H}, \mathrm{SCH}_{3}\right), 6.09\left(\mathrm{~s}, 2 \mathrm{H}, \mathrm{NH}_{2}\right), 7.56(\mathrm{~m}, 3 \mathrm{H}, \mathrm{Ar}-\mathrm{H})$, 7.89 (d, 2H, Ar-H), 11.97 (br. s, 1H, NH).

5-Amino-4-(4'-chlorophenylsulfonyl)-3-ethylthiopyrazole $3\{8\}$. Yield $-92 \%$. M. p. $-212-13{ }^{\circ} \mathrm{C} ;{ }^{1} \mathrm{H}$ NMR $\delta: 1.12$ (t, 3H, $\left.\mathrm{CH}_{3}\right), 2.87\left(\mathrm{q}, 2 \mathrm{H}, \mathrm{CH}_{2}\right), 6.17$ (s, $\left.2 \mathrm{H}, \mathrm{NH}_{2}\right), 7.64(\mathrm{~d}, 2 \mathrm{H}, \mathrm{Ar}-\mathrm{H}), 7.89$ (d, 2H, Ar-H), 12.00 (s, $1 \mathrm{H}, \mathrm{NH})$.

$\mathrm{N}$-(3,4-Dimethylphenyl)-(5-amino-4-metylsulfonyl-3-methylthiopyrazol-1-yl)acetamide $5\{36\}$. Yield $74 \%$. M. p. $-234-36{ }^{\circ} \mathrm{C} ;{ }^{1} \mathrm{H}$ NMR $\delta: 2.12\left(\mathrm{~s}, 6 \mathrm{H}, 2 \mathrm{CH}_{3}\right)$, $2.33\left(\mathrm{~s}, 3 \mathrm{H}, \mathrm{SCH}_{3}\right), 3.00\left(\mathrm{~s}, 3 \mathrm{H}, \mathrm{CH}_{3}\right), 4.74\left(\mathrm{~s}, 2 \mathrm{H}, \mathrm{CH}_{2}\right)$, $6.23\left(\mathrm{~s}, 2 \mathrm{H}, \mathrm{NH}_{2}\right), 7.03(\mathrm{~d}, 1 \mathrm{H}, \mathrm{Ar}-\mathrm{H}), 7.22(\mathrm{~d}, 1 \mathrm{H}, \mathrm{Ar}-\mathrm{H})$, 7.31 (s, 1H, Ar-H), 10.10 (s, 1H, NH); m/z: $369\left[\mathrm{M}^{+}\right]$.

$\mathrm{N}$-(2-Fluoro-4-bromophenyl)-(5-amino-4-phenylsulfonyl-3-methylthiopyrazol-1-yl)acetamide $5\{63\}$. Yield $-66 \%$. M. p. $-261-62{ }^{\circ} \mathrm{C} ;{ }^{1} \mathrm{H}$ NMR $\delta: 2.27$ (s, 3H, $\left.\mathrm{SCH}_{3}\right), 4.83$ (s, 2H, $\left.\mathrm{CH}_{2}\right), 6.50\left(\mathrm{~s}, 2 \mathrm{H}, \mathrm{NH}_{2}\right), 7.36$ (dd, 1H, Ar-H), 7.61 (s+m, 4H, Ar-H), 7.93 (m, 3H, Ar-H), $10.15(\mathrm{~s}, 1 \mathrm{H}, \mathrm{NH})$.

1-Benzyl-5-( $\mathrm{N}$-acetylamino)-4-phenylsulfonyl-3methylthiopyrazole $7\{2\}$. Yield $-71 \%$. M. p. $-253-55^{\circ} \mathrm{C}$; ${ }^{1} \mathrm{H}$ NMR $\delta: 2.08$ (t, 3H, $\mathrm{CH}_{3}$ ), 2.32 (s, 3H, $\left.\mathrm{SCH}_{3}\right), 5.08$<smiles>CSc1n[nH]c(N)c1S(=O)(=O)c1ccccc1</smiles><smiles>CSc1nn(CC(=O)Nc2ccc(Br)cc2F)c(N)c1S(=O)(=O)c1ccccc1</smiles><smiles>CCSc1n[nH]c(N)c1S(=O)(=O)c1ccc(Cl)cc1</smiles><smiles>[SiH3]</smiles><smiles>[Al]c1ccccc1</smiles><smiles>CSc1nn(CC(=O)Nc2ccc(C)c(C)c2)c(N)c1S(C)(=O)=O</smiles><smiles>CSc1nn(Cc2ccccc2)c(NC(C)=O)c1S(=O)(=O)c1ccccc1</smiles>

5 $\{91\}$<smiles>CCC(=O)N(C(=O)CC)c1c(S(=O)(=O)c2ccccc2)c(SC)nn1Cc1ccc(Br)cc1</smiles>

Fig. Examples of substituted 5-amino-3-alkylthiopyrazoles synthesized 
(s, 2H, $\left.\mathrm{CH}_{2}\right), 7.19(\mathrm{~d}, 2 \mathrm{H}, \mathrm{Ar}-\mathrm{H}), 7.29(\mathrm{~s}, 1 \mathrm{H}, \mathrm{Ar}-\mathrm{H})$, 7.32 (d, 2H, Ar-H), 7.58 (m, 3H, Ar-H), 7.90 (d, 2H,

Ar-H), 10.25 (s, $1 \mathrm{H}, \mathrm{NH}) ; \mathrm{m} / z$ : $402\left[\mathrm{M}^{+}\right]$.

1-(2,4-Dimetylbenzyl)-5-( $N$-propionylamino)-4phenylsulfonyl-3-methylthiopyrazole $7\{16\}$. Yield $57 \%$. M. p. $-282^{\circ} \mathrm{C} ;{ }^{1} \mathrm{H}$ NMR $\delta: 0.85\left(\mathrm{t}, 3 \mathrm{H}, \mathrm{CH}_{3}\right), 2.15$ (t, $\left.3 \mathrm{H}, \mathrm{CH}_{3}\right), 2.20\left(\mathrm{t}, 3 \mathrm{H}, \mathrm{CH}_{3}\right), 2.22\left(\mathrm{~m}, 2 \mathrm{H}, \mathrm{CH}_{2}\right), 2.44$ (s, $\left.3 \mathrm{H}, \mathrm{SCH}_{3}\right), 5.12\left(\mathrm{~s}, 2 \mathrm{H}, \mathrm{CH}_{2}\right), 6.84(\mathrm{~s}, 1 \mathrm{H}, \mathrm{Ar}-\mathrm{H})$, 7.04 (s, 2H, Ar-H), 7.57 (d, 2H, Ar-H), 7.74 (m, 3H, Ar-H), $10.20(\mathrm{~s}, 1 \mathrm{H}, \mathrm{NH}) ; \mathrm{m} / z: 444\left[\mathrm{M}^{+}\right]$.

1-(4-Bromobenzyl)-5-( $N, N$-dipropionylamino)-4phenylsulfonyl-3-methylthiopyrazole $9\{5\}$. Yield $-55 \%$.
M. p. $-219-21{ }^{\circ} \mathrm{C} ;{ }^{1} \mathrm{H}$ NMR $\delta: 0.85\left(\mathrm{t}, 6 \mathrm{H}, \mathrm{CH}_{3}\right), 2.35$ $\left(\mathrm{m}, 4 \mathrm{H}, 2 \mathrm{CH}_{2}\right), 2.45\left(\mathrm{~s}, 3 \mathrm{H}, \mathrm{SCH}_{3}\right), 5.19\left(\mathrm{~s}, 2 \mathrm{H}, \mathrm{CH}_{2}\right)$, 7.20 (d, 2H, Ar-H), 7.51 (d, 2H, Ar-H), 7.57-7.72 (m, $5 \mathrm{H}, \mathrm{Ar}-\mathrm{H}) ; \mathrm{m} / \mathrm{z}: 551\left[\mathrm{M}^{+}\right]$.

\section{CONCLUSIONS}

The method of the synthesis of series of new substituted 5-amino-3-alkylthiopyrazoles has been developed. They are of great interest for further biological screening in order to find substances with the properties associated with the action on fungal cells among them.

Conflict of Interests: authors have no conflict of interests to declare.

\section{REFERENCES}

1. Antimicrobial Stewardship from Policy to Practice : Experiences from UK Antimicrobial Pharmacists / M. Gilchrist, P. Wade, D. AshiruOredope et al. // Infect. Dis. Ther. - 2015. - Vol. 4, Issue 1. - P. 51-64. doi: 10.1007/s40121-015-0080-Z

2. Calugi, C. Novel small molecules for the treatment of infections caused by Candida albicans : a patent review (2002-2010) / C. Calugi, A. Trabocchi, A. Guarna // Expert Opin. Ther. Pat. - 2011. - Vol. 21, Issue 3. - P. 381-397. doi: 10.1517/13543776.2011.551116

3. Centers for Disease Control and Prevention. Global Fungal Diseases. - Available at : http://www.cdc.gov/fungal/global/index.html

4. Cleveland, A. A. Changes in incidence and antifungal drug resistance in candidemia: results from population-based laboratory surveillance in Atlanta and Baltimore, 2008-2011 / A. A. Cleveland, M. M. Farley, L. H. Harrison // Clin. Infect. Dis. - 2012. - Vol. 55, Issue 10. P. 1352-1361. doi: 10.1093/cid/cis697

5. Introduction of an antifungal stewardship programme targeting high-cost antifungals at a tertiary hospital in Cambridge, England / C. Micallef, S. H. Aliyu, R. Santos et al. // J. Antimicrob. Chemother. - 2015. - Vol. 70, Issue 6. - P. 1908-1911. doi: 10.1093/jac/dkv040

6. Ruhnke, M. Antifungal stewardship in invasive Candida infections / M. Ruhnke // Clin. Microbiol. Infect. - 2014. - Vol. 20, Issue 6. P. 11-18. doi: 10.1111/1469-0691.12622

7. Effects of Membrane PEGylation on Entry and Location of Antifungal Drug Itraconazole and Their Pharmacological Implications / M. Dzieciuch-Rojek, C. Poojari, J. Bednar et al. // Mol. Pharmaceutics. - 2017. - Vol. 14, Issue 4. - P. 1057-1070. doi: 10.1021/acs. molpharmaceut.6b00969

8. Synthetic Approaches to New Drugs Approved During 2015 / A. C. Flick, H. X. Ding, C. A Leverett et al. // J. Med. Chem. - 2017. doi: 10.1021/acs.jmedchem.7b00010

9. Tackling Fungal Resistance by Biofilm Inhibitors / Sh. Wu, Y. Wang, N. Liu et al. // J. Med. Chem. - 2017. - Vol. 60, Issue 6. P. 2193-2211. doi: 10.1021/acs.jmedchem.6b01203

10. Rösch, A. How Biotransformation Influences Toxicokinetics of Azole Fungicides in the Aquatic Invertebrate Gammarus pulex / A. Rösch, S. Anliker, J. Hollender // Environ. Sci. Technol. - 2016. - Vol. 6, Issue 13. - P. 7175-7188. doi: 10.1021/acs.est.6b01301

11. Recent advanced in bioactive systems containing pyrazole fused with a five membered heterocycle / D. Raffa, B. Maggio, M. V. Raimondi et al. // Eur. J. Med. Chem. - 2015. - Vol. 97, Issue 5. - P. 732-746. doi: 10.1016/j.ejmech.2014.12.023

12. Review : biologically active pyrazole derivatives / A. Ansari, A. Ali, M. Asifa, Shamsuzzaman // New J. Chem., - 2017. - Vol. 41, Issue 1. P. 16-41. doi: 10.1039/C6NJ03181A

13. Synthesis and antifungal activities of diaryl pyrazoles carboxamide derivatives / A. Patil, R. Jadhav, H. Raundal et al. // J. Chem. Pharm. Res. - 2014. - Vol. 6, Issue 8. - P. 218-223.

14. Synthesis and antimicrobial activity of 3-aroyl-4-heteroaryl pyrroles and pyrazoles / Sh. Sh. Basha, P. R. Reddy, A. Padmaja et al. // Med. Chem. Res. - 2015. - Vol. 24, Issue 3. - P. 954-964. doi: 10.1007/s00044-014-1169-8

15. Synthesis and biological evaluation of 1,3-diaryl pyrazole derivatives as potential antibacterial and anti-inflammatory agents / Y.-R. Li, Ch. Li, J.-Ch. Liu et al. // Bioorg. Med. Chem. Lett. - 2015. - Vol. 25, Issue 22. - P. 5052-5057. doi: 10.1016/j.bmcl.2015.10.028

16. Synthesis and fungicidal activity of pyrazole derivatives containing 1,2,3,4-tetrahydroquinoline / P. Lei, X. Zhang, Y. Xu et al. // Chem. Cent. J. - 2016. - doi: 10.1186/s13065-016-0186-8

17. Синтез и противомикробная активность 4-арилсульфонилпроизводных 5-аминопиразолов / П. В. Ткаченко, Е. В. Ткаченко, И. А. Журавель и др. // Вестник КазНМУ. - 2017. - № 2. - С. 307-311.

18. Activity prediction for a chemical substance. - Available at : http://genexplain.com/pass/

\section{REFERENCES}

1. Gilchrist, M., Wade, P., Ashiru-Oredope, D., Howard, P., Sneddon, J., Whitney, L., Wickens, H. (2015). Antimicrobial Stewardship from Policy to Practice: Experiences from UK Antimicrobial Pharmacists. Infectious Diseases and Therapy, 4 (1), 51-64. doi: 10.1007/ s40121-015-0080-Z

2. Calugi, C., Trabocchi, A., Guarna, A. (2011). Novel small molecules for the treatment of infections caused by Candida albicans: a patent review (2002-2010) (2011). Expert Opinion on Therapeutic Patents, 27 (6), 381-397. doi: 10.1517/13543776.2011.551116

3. Centers for Disease Control and Prevention. Global Fungal Diseases. Available at: http://www.cdc.gov/fungal/global/index.html

4. Cleveland, A. A., Farley, M. M., Harrison, L. H. (2012). Changes in incidence and antifungal drug resistance in candidemia: results from population-based laboratory surveillance in Atlanta and Baltimore, 2008-2011. Clinical Infectious Diseases, 55 (10), $1352-1361$. doi: $10.1093 /$ cid/cis697 
5. Micallef, C., Aliyu, S. H., Santos, R., Brown, N. M., Rosembert, D., Enoch, D. A. (2015). Introduction of an antifungal stewardship programme targeting high-cost antifungals at a tertiary hospital in Cambridge, England. Journal of Antimicrobial Chemotherapy, 70 (6), 1908-1911. doi: 10.1093/jac/dkv040

6. Ruhnke, M. (2014). Antifungal stewardship in invasive Candida infections. Clinical Microbiology and Infection, 20 (6), 11-18. doi: 10.1111/1469-0691.12622

7. Dzieciuch-Rojek, M., Poojari, C., Bednar, J., Bunker, A., Kozik, B., Nowakowska, M., Vattulainen, I., Wydro, P., Kepczynski, M., Róg, T. (2017). Effects of Membrane PEGylation on Entry and Location of Antifungal Drug Itraconazole and Their Pharmacological Implications. Molecular Pharmaceutics, 14 (4), 1057-1070. doi: 10.1021/acs.molpharmaceut.6b00969

8. Flick, A.C., Ding, H. X., Leverett, C. A., Kyne, R. E., Liu, K., Fink, S. J., O’Donnel, C. J. (2017). Synthetic Approaches to New Drugs Approved During 2015. Journal of Medicinal Chemistry. doi: 10.1021/acs.jmedchem.7b00010

9. Wu, Sh., Wang, Y., Liu, N., Dong, G., Sheng, C. (2017). Tackling Fungal Resistance by Biofilm Inhibitors. Journal of Medicinal Chemistry, 60 (6), 2193-2211. doi: 10.1021/acs.jmedchem.6b01203

10. Rösch, A., Anliker, S., Hollender, J. (2016). How Biotransformation Influences Toxicokinetics of Azole Fungicides in the Aquatic Invertebrate Gammarus pulex. Environmental Science \& Technology, 6 (13), 7175-7188. doi: 10.1021/acs.est.6b01301

11. Raffa, D., Maggio, B., Raimondi, M. V., Cascioferro, S., Cancemi, G., Daidone, G. (2015). Recent advanced in bioactive systems containing pyrazole fused with a five membered heterocycle. European Journal of Medicinal Chemistry, 97 (5), 732-746. doi: 10.1016/j. ejmech.2014.12.023

12. Ansari, A., Ali, A., Asifa, M., Shamsuzzaman (2017). Review: biologically active pyrazole derivatives. New Journal of Chemistry, 41 , 16-41. doi: 10.1039/C6NJ03181A

13. Patil, A., Jadhav, R., Raundal, H., Sharma, L., Badgujar, R., Bobade, V. (2014). Synthesis and antifungal activities of diaryl pyrazoles carboxamide derivatives. Journal of Chemical and Pharmaceutical Research, 6 (8), 218-223.

14. Basha, Sh. Sh., Reddy, P. R., Padmaja, A., Padmavathi, V., Mouli, K. C., Vijaya, T. (2015). Synthesis and antimicrobial activity of $3-$ aroyl-4-heteroaryl pyrroles and pyrazoles. Medicinal Chemistry Research, 24 (3), 954-964. doi: 10.1007/s00044-014-1169-8

15. Li, Y.-R., Li, Ch., Liu, J.-Ch., Guo, M., Zhang, T.-Y., Sun, L.-P., Zheng, C.-J., Piao, H.-R. (2015). Synthesis and biological evaluation of 1,3-diaryl pyrazole derivatives as potential antibacterial and anti-inflammatory agents. Bioorganic \& Medicinal Chemistry Letters, 25 (22), 5052-5057. doi: 10.1016/j.bmcl.2015.10.028

16. Lei, P., Zhang, X., Xu, Y., Xu, G., Liu, X., Yang, X., Zhang, X., Ling, Y. (2016). Synthesis and fungicidal activity of pyrazole derivatives containing 1,2,3,4-tetrahydroquinoline. Chemistry Central Journal. doi: 10.1186/s13065-016-0186-8

17. Tkachenko, P. V., Tkachenko, E. V., Zhuravel, I. A., Kazmirchuk, V. V., Derbisbekova, U. B. (2017). Vestnik KazNMU, 2, $307-311$.

18. Activity prediction for a chemical substance. Available at: http://genexplain.com/pass/

Information about autors:

Tkachenko P. V., postgraduate student of the Drug and Analytical Toxicology Department, National University of Pharmacy. E-mail: toxchem@nuph.edu.ua

Tkachenko O. V., Candidate of Pharmacy (Ph.D.), associate professor of the Quality Management Department, National University of Pharmacy.

E-mail: elena_tkachenko75@ukr.net

Netosova K. Yu., Candidate of Pharmacy (Ph.D.), assistant professor of the Drug and Analytical Toxicology Department, National University of Pharmacy.

E-mail: kulikovskaja.k@gmail.com

Borisov O. V., Candidate of Chemistry (Ph. D.), head of the laboratory of LLC "RPE "Enamine”. E-mail: boav.79@gmail.com

Zhuravel I. O., Doctor of Chemistry (Dr. habil.), professor, head of the Department of Clinical Biochemistry, Forensic Toxicology and Pharmacy,

Kharkiv Medical Academy of Postgraduate Education. E-mail: irina.tox@gmail.com

Відомості про авторів:

Ткаченко П. В., аспірант кафедри лікарської та аналітичної токсикології, Національний фармацевтичний університет. E-mail: toxсhеm@nuph.edu.uа

Ткаченко О. В., канд. фармац. наук, доцент кафедри управління якістю, Національний фармацевтичний університет. E-mail: elena tkachenko75@ukr.net

Нетьосова К. Ю., канд. фармац. наук, асистент кафедри лікарської та аналітичної токсикології, Національний фармацевтичний університет.

E-mail: kulikovskaja.k@gmail.com

Борисов О. В., канд. хім. наук, завідувач лабораторії ТОВ «НВП «Єнамін». E-mail: boav.79@gmail.com

Журавель І. О., д-р хім. наук, професор, завідувач кафедри клінічної біохімії, судово-медичної токсикології та фармації,

Харківська медична академія післядипломної освіти. E-mail: irina.tox@gmail.com

Сведения об авторах:

Ткаченко П. В., аспирант кафедры лекарственной и аналитической токсикологии, Национальный фармацевтический университет. Е-таil: toxсhеm@nuph.edu.ua Ткаченко Е. В., канд. фармац. наук, доцент кафедры управления качеством, Национальный фармацевтический университет. E-mail: elena_tkachenko75@ukr.net Нетёсова К. Ю., канд. фармац. наук, ассистент кафедры лекарственной и аналитической токсикологии, Национальный фармацевтический университет.

E-mail: kulikovskaja.k@gmail.com

Борисов А. В., канд. хим. наук, заведующий лабораторией ООО «НПП «Енамин». Е-mail: boav.79@gmail.com

Журавель И. А., д-р хим. наук, профессор, заведующий кафедрой клинической биохимии, судебно-медицинской токсикологии и фармации,

Харьковская медицинская академия последипломного образования. E-mail: irina.tox@gmail.com 